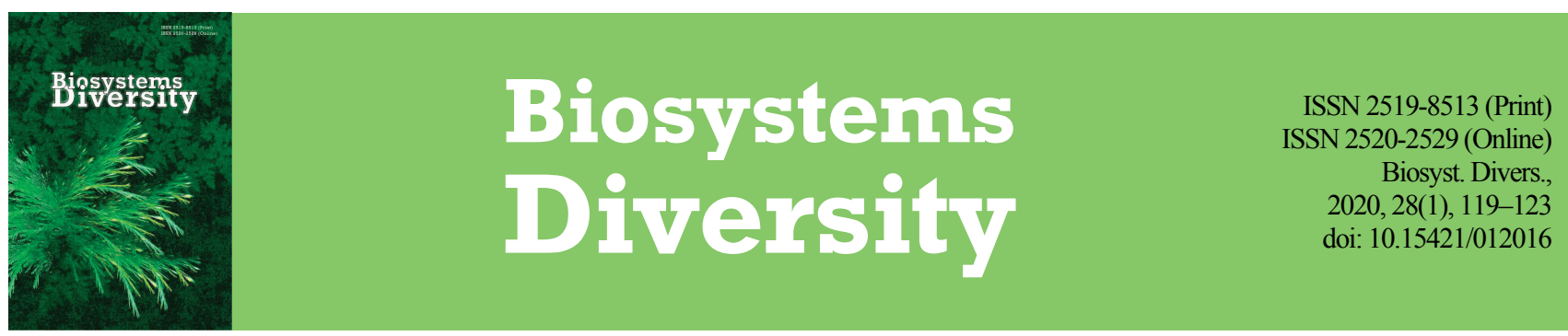

\title{
Nematicidal activity of aqueous tinctures of medicinal plants against larvae of the nematodes Strongyloides papillosus and Haemonchus contortus
}

\author{
O. O. Boyko*, A. M. Kabar**, V. V. Brygadyrenko** \\ *Dnipro State Agrarian and Economic University, Dnipro, Ukraine \\ **Oles Honchar Dnipro National University, Dnipro, Ukraine
}

Article info

Received 12.02.2020

Received in revised form 07.03 .2020

Accepted 09.03.2020

Dnipro State Agrarian and

Economic University,

Sergiy Efremov st., 25 ,

Dnipro, 49000, Ukraine.

Tel.: +38-097-296-42-10

E-mail:

boikoalexandra1982@gmail.com

Oles Honchar Dnipro National University, Gagarin av., 72, Dnipro, 49010, Ukraine. $\mathrm{Tel}:+38-050-93-90-788$

E-mail:brigad@ua.fm

\section{Introduction}

The health of agricultural animals, including the intensity of their infection with parasites, depends on the conditions of their maintenance. An important aspect regarding their productivity, both during stable maintenance and the grazing period, is the animals' diet (Zazharska et al., 2018). In the pastures, the process of the formation of parasitic fauna is affected by various factors. The most important among the biotic factors are temperature regime, parameters of moisture, mechanical composition of soil, its moisture penetrability, level of salinity, etc. (Boyko, 2008a, 2008b; Yevstafieva et al., 2019). At the same time, none of the separate factors in themselves has a great effect, for it is their mutual impact on parasites which is important. A significant role is played by the species composition of the parasitofauna, relations between all species of the pasture community, including agricultural animals, earthworms, mollusks, Acari and insects - the inhabitants of the pastures' soils and feces of mammals, and also various species of meadow grasses. The impact of invertebrates on the life cycles of the parasites of animals, their distribution and survival in the environment in most cases are studied sufficiently. A relevant aspect is the effect of the preparations or substances of non-synergic origin (Boyko \& Brygadyrenko, 2018, 2019a), medicinal and other species of plants on the survival of parasites in the organism of the host in the environment (Boyko \& Brygadyrenko, 2019b).

Anthelmintic properties of plants against parasites of agricultural animals are being studied all around the world. Gogoi et al. (2016) evaluated in vitro and in vivo potential anthelminth actions of extract from leaves of Caesalpinia bonducella (L.) against Syphacia obvelata (Rud, 1802) (Nematoda) and Hymenolepis diminuta (Rudolphi, 1819) (Cestoda): significant anthelmintic action of the extract was seen towards both parasites. In the in vitro experiment, the concentration of the extract in the amount of $30 \mathrm{mg} / \mathrm{mL}$ caused death to $H$. diminuta after $2.5 \pm 0.2 \mathrm{~h}$ and $S$. obvelata after $3.6 \pm 0.2 \mathrm{~h}$. These studies confirm the fact that the extract from leaves of $C$. bonducella has a significant anthelmintic effect. Decoction of bark of Oroxylum indicum (L.) Kurz. (Bignoniaceae) is used in India as a traditional medicine for the treatment of helminthiases of the digestive tract. Deori et al. (2015) studied in vitro and also in vivo anthelminth efficacy of the methanol extract of bark of $O$. indicum against $H$. diminuta; the authors have confirmed that the extract of bark of $O$. indicum has an antiparasitic effect against larvae and adult helminths of $H$. diminuta.

Aqueous and chloroform extracts from coconut, onion, garlic, fig, Phoenix, Cichorium, pineapple and Cistus cyprius were tested against cestodes and trematodes. Abdel-Ghaffar et al. (2010) performed in vivo and in vitro experiments for anthelminth activity against cestodes of H. diminuta, H. microstoma Dujardin, 1845, Taenia taeniaeformis Batsch, 1786, and also trematodes of Fasciola hepatica Linnaeus, 1758 (Trematoda) and Echinostoma caproni. In all in vitro tests the parasites were killed. The treatment of mice and rats with combination of the extracts from onion and coconut caused death to all the cestodes. The same composition was effective against $E$. caproni. However, it was ineffective against $F$. hepatica in the definitive host. Nonetheless, in in vitro experiment, $F$. hepatica trematodes died under the effect of the extracts from this species of plants. Inoculation of fluids of coconut was lethal to $T$. taeniaeformis in naturally-infected cats.

The effects of plants on $H$. diminuta were also studied by Yadav et al. (2010). They evaluated anthelmintic activity of methanol extract of ripe fruits of Solanum myriacanthum Dunal with use of $H$. diminuta in albino rats. Solanum myriacanthum is a perennial shrub used in folk medicine of one of the Indian tribes for treatment against intestinal helminths. Plant extract exhibited decrease in the amount of produced eggs of helminths, and also number of helminths of $H$. diminuta at all stages of the development in rats depending on the concentration of the extract. The greatest effect by the methanol extract was shown against mature stage of $H$. diminuta. Against this species of parasite, anthelmintic effect was exerted by Psidium guajava L. and Lasia spinosa (L.) 
Thwaites (Temjenmongla et al., 2015). The parasitic nematode Haemonchus contortus (Rudolphi, 1803) Cobb, 1898 is one the commonest species of helminths of sheep and goats. In Kenya, measures against this parasite are taken using anthelmintic preparations of synthetic origin. Githiori et al. (2003) tested 10 species of plants in the in vivo experiment on $H$. contortus of sheep. Among the plants tested on sheep, the most significant decrease in the number of eggs equaling $34 \%$ was displayed by bark of $A$. anthelmintica (A. Rich.) Brogn. The rest of the studied species of plants had no significant effect on $H$. contortus of sheep. Thus, $H$. contortus is a nematode which is quite resistant to various factors. Therefore, the objective of our study was the evaluation of in vitro nematocidial properties of 48 species of medical plants on nematode larvae of $S$. papillosus and $H$. contortus in different stages.

\section{Material and methods}

In the experiment, feces of small ruminants were used. Goats were maintained in the territory of clinical-diagnostic center of the Dnipro State Agrarian-Economic University (Dnipro, Ukraine). The maintenance conditions of goats were satisfactory. In summer the goats grazed, and spent some time on the premises. The animals had free access to food and water. The feces were surveyed for the presence of eggs of nematodes, cestodes, trematodes, larvae of lung nematodes of sheep. The feces were analyzed using McMaster and Baermann tests (Zajac et al., 2011). The cultures of $S$. papillosus were grown in fresh $(1-5 \mathrm{~h})$ feces of goats. Exposure of the cultivation of S. papillosus and H. contortus larvae lasted for 8 days. The larvae were obtained using the Baermann method. For this purpose, $15 \mathrm{~g}$ of feces with cultivated larvae were covered by $20 \mathrm{~mL}$ of distilled warm $\left(36^{\circ} \mathrm{C}\right)$ water. The exposure for the emergence of larvae from the goats' feces was $2-4 \mathrm{~h}$.

Then, the distilled water with larvae were poured by $4 \mathrm{~mL}$ into test tubes and centrifuged for $5 \mathrm{~min}$ at 1,500 rpm. Total of $3 \mathrm{~mL}$ of supernatant fluid was removed with a pipette. The sediment with larvae $(1 \mathrm{~mL})$ was uniformly stirred and put into test tubes $(1.5 \mathrm{~mL})$ by $0.1 \mathrm{~mL}$ in each. In the experiment, we used five concentrations of aqueous tincture (Table 1) for each of the 48 species of plants. Each variant of the experiment was replicated seven times $(n=7)$. In the control, nematode larvae were kept in aqueous tinctures of plants for $24 \mathrm{~h}$. Then, in the contents of each test tube, the number of live and dead invasive (filarial) and non-invasive (rhabditiform) larvae was counted. The data in the Tables are given in the form of mean \pm mean square deviation $(x \pm \mathrm{SD})$.

\section{Results}

Higher resistance to the influence of the tinctures of medical plants was seen in the invasive nematode larvae of the surveyed species (S. papillosus and $H$. contortus). The highest mortality of larvae (Table 1 ) was observed during exposure to 3\% aqueous tinctures of Wisteria sinensis (Sims) DC., Ailanthus altissima (Mill.) Swingle, Laburnum anagyroides Medik., Quercus petraea subsp. iberica (Steven ex M. Bieb.) Krassiln., Ginkgo biloba L., Colchicum autumnale L., Aristolochia manshuriensis Kom., Celastrus scandens L., Securigera varia (L.) Lassen, Magnolia kobus DC. The percentage of killed specimens was within 90-98\%.

Under the effect of $0.75 \%$ solutions of Juniperus sabina L., L. anagyroides, A. altissima, W. sinensis, C. scandens, A. manshuriensis, M. kobus, $S$. varia, G. biloba, the percentage of dead larvae amounted to over $50 \%$, ranging within $50-80 \%$. Lower concentrations of the tinctures of plants exerted no effect against non-invasive larvae of nematodes. Over $24 \mathrm{~h}$ of exposure to aqueous solutions of the medical plants in lower concentrations, more than $50 \%$ of $S$. papillosus non-invasive larvae and $100 \%$ of invasive nematode larvae survived (Table 1).

The lowest $\mathrm{LD}_{50}$ parameters were recorded for L. anagyroides, J. sabina, C. scandens, M. kobus, A. manshuriensis, W. sinensis, S. varia. Invasive nematode larvae of $S$. papillosus and $H$. contortus were resistant to the effect of even 3\% solutions of aqueous tinctures. However, among these two species of nematodes, the more susceptible to the effect were the invasive larvae of S. papillosus. The highest effect was exhibited by $3 \%$ aqueous tinctures of $M$. kobus, Q. petraea, C. autumnale and $C$. scandens. During $24 \mathrm{~h}$ exposure to $3 \%$ tincture of these plants, on average $10-11 \%$ of the specimens of S. papillosus invasive larvae died (Table 2).

\section{Discussion}

Therefore, several species of plants were distinguished which have a negative effect on larvae of S. papillosus. And although mostly the larvae of first and second stages of the development died, more detailed understanding of the peculiarities of some of these plants' chemical composition, as well as their use in medicine and veterinary medicine, is required for future experiments against the free-living stages of parasites in the environment.

Wisteria sinensis (Sims) DC. is one of the plants we studied in 3\% aqueous tincture with notable nematocidial properties. It also has antioxidant and antibacterial properties. Wisteria sinensis contains large amounts of polyphenols, saponins, flavons and lectins. Keskin et al. (2019) consider that having such properties the plant can be used for treatment of rheumatoid arthritis, diseases of the stomach and the mammary gland. Jiang et al. (2009) demonstrated the inhibiting effect of $W$. sinensis on fungi and bacteria (these authors used acetyl extract from leaves of $W$. sinensis). These experiments, according to the authors, require further research in the sphere of the development of agricultural chemicals. Mohamed et al. (2019) also performed research using fat-free aqueous $80 \%$ methanol extract from leaves of $W$. sinensis. For the first time they report that this extracts has notable cytotoxic activity towards Hep-G2 line of tumour cells, in addition to antioxidant activity. Our studies, in turn, also indicate the need for further survey of nematocidial properties of this plant using other methods of extracting the active substances.

Ailanthus altissima (Mill.) Swingle is used in traditional Chinease medicine for the treatment against colds and stomach diseases. Ailanthus altissima contains essential oils of different parts of the plant: roots, stems, leaves, flowers and ripe fruits. Ayeb-Zakhama et al. (2014) extracted 69 compounds. They were represented by $91.0-97.2 \%$ of all oil composition. Essential oil from the root contains large amounts of aldehydes $(22.6 \%)$, whereas the leaves mostly contain oxygen-enriched sesquiterpenes $(42.1 \%)$. Essential oil was rich in derivative of apocarotenoids, hexahydrofarnesyl acetate $(58.0 \%)$, and the oil obtained from stems was characterized by sesquiterpene hydrocarbons (54.1\%), mainly $\beta$-caryophyllene (18.9\%). These authors also report phytotoxic effect of A. altissima.

Albouchi et al. (2013) also studied the chemical composition of A. altissima, its antioxidant, antimicrobial and phytotoxic activity. They performed a complex study of volatile oils and phenol components of leaves of A. altissima. In the experiment, methanol extracts of leaves and their hydrodistilled remains were used. The essential oils from leaves were found to contain over hundred constituents. Most of them are represented by non-terpene compounds (tetradecanol, heneicosane, tricosane and docosane), and also sesquiterpene hydrocarbons ( $\alpha$-curcumene and $\alpha$-gurjunene). Methanol extracts from leaves contain higher amount of phenols, while extracts from hydrodistilled remains - high total content of flavonoids. Most commonly found phenol compounds were gallic acid, chlorogenic acid, HHDP-galloylglucose, epicatechin, rutin, hyperoside and quercetin-3-galloylglucoside. Both extracts exerted strong antioxidant activity depending on the concentration. These extracts are efficient against Gram-positive bacteria (Albouchi et al., 2013) and inactive towards Gram-negative bacteria and Candida albicans. They also exhibited high inhibiting effect on germination and growth of rots of wild carrot Daucus carota L. Phenol components of extracts from leaves of A. altissima (methanol and aqueous extracts), their antibacterial and anti-fungal properties were studied by Poljuha et al. (2017). Methanol extract contained more phenol, phlavonoid and nonphlavonoid compounds, and also had more notable antioxidant activity than aqueous extracts. Acetone extract from leaves displayed activity against Escherichia coli. Acetone, methanol and dichloromethane extracts had high activity towards Candida albicans (Poljuha et al., 2017).

Ailanthus altissima contains proteins, flavonoids, alkaloids, quassinoids, terpinyl coumarins, tetracyclic triterpenoids, fatty acids, essential oils and many other active compounds. Al-Snafi (2015) report antibacterial, antiviral, antioxidant, cytotoxic, anti-diarrhea, anti-inflammatory, 
antipyretic, anesthetic, antihistamine, antiparasitic, repellent, anti-progesterone activities of this medical plant. Bary et al. (1987) and also Okunade et al. (2003) studied in vitro antiplasmodial activity of A. altissima.

Studies were conducted for the in vitro effect of bark of $A$. altissima on Psoroptes cuniculi (Delafond, 1859) and Sarcoptes scabiei (Linnaeus, 1758). In the concentrations of $1.00,0.50$ and $0.25 \mathrm{~g} / \mathrm{mL}, 100 \%$ of S. scabiei died over $7 \mathrm{~h}$ exposure. The concentrations of 1.0 and $0.5 \mathrm{~g} / \mathrm{mL}$ killed all the tested $P$. cuniculi (Gu et al., 2014). Repellent and fumigative effects were exerted by essential oil of $A$. altissima (Lü et al., 2011). Also, mollusicidal effect of $A$. altissima was confirmed (Jiang et al., 2013). In their studies, El-Rigal et al. (2006) demonstrated antiparasitic and repellent effects of the extract of chlorophorm of stem bark of A. altissima. The scientists revealed antischistosomal and hepatoprotec- tive effects. Also, during the use of this extract, they observed decrease in the number of helminths in mice. Methanol extracts of different parts of plant $A$. altissima were tested against root-knot nematode Meloidogyne javanica (Caboni et al., 2012). According to the results of our studies, A. altissima has also nematocidial properties against S. papillosus nematode larvae in the first and second stages of the development.

Laburnum anagyroides Medik. is consumed by larvae of some species of lepidopterans as food. Laburnum anagyroides is considered a poisonous plant (Forrester, 1979). The plant's main toxin is cytosine. The symptoms of poisoning can manifest in strong somnolence, nausea, vomiting, diarrhea, spasmodic movements and even coma. Perhaps, toxic properties of this poisonous plant also negatively affected the larvae of the first and second stages of S. papillosus nematodes.

\section{Table 1}

Mortality (\%) of non-invasive larvae of S. papillosus $\mathrm{L}_{1-2}$ during 24 h laboratory experiment $(\mathrm{x} \pm \mathrm{SD}, \mathrm{n}=7)$ exposed to aqueous tinctures of leaves from 48 species of plants

\begin{tabular}{|c|c|c|c|c|c|c|c|c|}
\hline Family & Species & $\begin{array}{l}\text { Mortality of } \\
\text { nematode } \\
\text { larvae in } \\
3.0 \% \text { plant } \\
\text { solution, \% }\end{array}$ & $\begin{array}{l}\text { Mortality of } \\
\text { nematode } \\
\text { larvae in } \\
0.75 \% \text { plant } \\
\text { solution, \% }\end{array}$ & $\begin{array}{c}\text { Mortality of } \\
\text { nematode } \\
\text { larvae in } \\
0.188 \% \text { plant } \\
\text { solution, \% }\end{array}$ & $\begin{array}{c}\text { Mortality of } \\
\text { nematode } \\
\text { larvae in } \\
0.047 \% \text { plant } \\
\text { solution, \% }\end{array}$ & $\begin{array}{c}\text { Mortality of } \\
\text { nematode } \\
\text { larvae in } \\
0.012 \% \text { plant } \\
\text { solution, \% }\end{array}$ & $\begin{array}{l}\text { Mortality of } \\
\text { nematode } \\
\text { larvae in } \\
\text { control, \% }\end{array}$ & $\mathrm{LD}_{50}, \%$ \\
\hline Anacardiaceae & Cotinus coggygria Scop. & $28.2 \pm 1.9$ & $7.8 \pm 0.9$ & $6.1 \pm 1.4$ & $5.7 \pm 1.6$ & $6.4 \pm 0.6$ & $3.7 \pm 2.1$ & - \\
\hline - & Rhus trilobata Nutt. & $48.5 \pm 5.4$ & $32.2 \pm 3.2$ & $14.3 \pm 1.7$ & $10.8 \pm 1.1$ & $10.3 \pm 0.3$ & $11.9 \pm 1.6$ & - \\
\hline ““- & Rhus typhina $\mathrm{L}$. & $19.4 \pm 2.2$ & $10.0 \pm 1.0$ & $5.9 \pm 0.4$ & $5.1 \pm 2.3$ & $3.7 \pm 1.2$ & $3.2 \pm 1.2$ & - \\
\hline -“- & Toxicodendron orientale Greene & $79.3 \pm 3.2$ & $47.7 \pm 3.1$ & $14.0 \pm 2.8$ & $7.4 \pm 2.2$ & $8.6 \pm 1.6$ & $11.9 \pm 1.6$ & 0.90 \\
\hline Araliaceae & Aralia elata (Miq.) Seem. & $65.7 \pm 1.7$ & $51.8 \pm 3.8$ & $20.1 \pm 1.6$ & $6.1 \pm 3.1$ & $4.3 \pm 1.4$ & $3.2 \pm 1.2$ & 0.75 \\
\hline - & Hedera helix $\mathrm{L}$. & $39.7 \pm 6.7$ & $12.0 \pm 3.1$ & $5.9 \pm 1.8$ & $3.9 \pm 2.0$ & $4.1 \pm 1.4$ & $3.7 \pm 2.1$ & - \\
\hline Asparagaceae & Polygonatum multiflorum (L.) All. & $23.7 \pm 5.6$ & $12.0 \pm 3.1$ & $5.9 \pm 1.8$ & $3.9 \pm 2.0$ & $4.1 \pm 1.4$ & $3.7 \pm 2.1$ & - \\
\hline Berberidaceae & Berberis vulgaris L. & $46.9 \pm 4.9$ & $23.6 \pm 1.9$ & $15.9 \pm 3.4$ & $13.4 \pm 3.4$ & $8.0 \pm 1.7$ & $7.1 \pm 2.8$ & - \\
\hline -“- & Mahonia aquifolium (Pursh) Nutt. & $35.4 \pm 8.2$ & $15.5 \pm 1.1$ & $13.3 \pm 1.4$ & $8.7 \pm 1.8$ & $8.2 \pm 0.7$ & $7.1 \pm 2.8$ & - \\
\hline Bignoniaceae & Campsis radicans (L.) Seem. & $48.9 \pm 3.4$ & $19.4 \pm 2.4$ & $11.5 \pm 1.9$ & $11.4 \pm 2.5$ & $9.1 \pm 1.2$ & $11.1 \pm 0.9$ & - \\
\hline -“- & Catalpa fargesii Bureau & $27.3 \pm 2.6$ & $21.9 \pm 0.8$ & $11.0 \pm 0.8$ & $10.5 \pm 2.3$ & $10.4 \pm 1.4$ & $11.9 \pm 1.6$ & - \\
\hline Calycanthaceae & Chimonanthus praecox (L.) Link & $25.7 \pm 1.9$ & $14.8 \pm 2.6$ & $6.5 \pm 1.4$ & $3.1 \pm 1.4$ & $3.0 \pm 1.3$ & $3.7 \pm 2.1$ & - \\
\hline Celastraceae & Aristolochia manshuriensis Kom. & $94.6 \pm 1.7$ & $70.5 \pm 3.9$ & $46.2 \pm 2.6$ & $13.8 \pm 3.0$ & $7.6 \pm 1.4$ & $7.1 \pm 2.8$ & 0.24 \\
\hline -“- & Celastrus scandens L. & $92.5 \pm 1.4$ & $70.0 \pm 2.7$ & $47.1 \pm 3.0$ & $13.9 \pm 2.3$ & $8.6 \pm 1.1$ & $7.1 \pm 2.8$ & 0.23 \\
\hline Colchicaceae & Colchicum autumnale $\mathrm{L}$. & $92.8 \pm 2.2$ & $49.1 \pm 2.9$ & $15.7 \pm 2.9$ & $13.5 \pm 2.2$ & $8.0 \pm 1.0$ & $7.1 \pm 2.8$ & 0.80 \\
\hline Cupressaceae & $\begin{array}{l}\text { Chamaecyparis lawsoniana } \\
\text { (A. Murray bis) Parl. }\end{array}$ & $72.3 \pm 5.9$ & $46.7 \pm 1.9$ & $10.0 \pm 2.0$ & $8.5 \pm 3.1$ & $6.3 \pm 2.7$ & $3.2 \pm 1.2$ & 1.08 \\
\hline -“- & Juniperus sabina L. & $85.7 \pm 2.0$ & $71.5 \pm 3.1$ & $47.3 \pm 3.6$ & $17.9 \pm 2.5$ & $10.7 \pm 1.1$ & $11.9 \pm 1.6$ & 0.22 \\
\hline Dennstaedtiaceae & Pteridium aquilinum (L.) Kuhn & $61.5 \pm 1.8$ & $37.6 \pm 1.7$ & $22.8 \pm 1.7$ & $16.6 \pm 2.7$ & $10.5 \pm 1.2$ & $11.9 \pm 1.6$ & 1.93 \\
\hline Eucommiaceae & Eucommia ulmoides Oliv. & $50.7 \pm 12.5$ & $21.4 \pm 4.2$ & $6.3 \pm 1.7$ & $2.9 \pm 1.3$ & $3.3 \pm 2.1$ & $3.7 \pm 2.1$ & 2.94 \\
\hline Fabaceae & Genista tanaitica P. A. Smirn. & $41.0 \pm 4.2$ & $20.8 \pm 1.8$ & $10.1 \pm 2.3$ & $6.4 \pm 2.6$ & $5.4 \pm 2.7$ & $3.2 \pm 1.2$ & - \\
\hline -“- & Laburnum anagyroides Medik. & $90.7 \pm 1.6$ & $66.7 \pm 3.5$ & $48.9 \pm 4.4$ & $21.5 \pm 2.2$ & $7.8 \pm 1.2$ & $7.1 \pm 2.8$ & 0.19 \\
\hline -“- & Securigera varia (L.) Lassen & $91.7 \pm 1.3$ & $79.2 \pm 5.9$ & $15.4 \pm 4.8$ & $10.1 \pm 1.2$ & $7.7 \pm 1.0$ & $7.1 \pm 2.8$ & 0.48 \\
\hline -“- & $\begin{array}{l}\text { Styphnolobium japonicum (L.) } \\
\text { Schott }\end{array}$ & $63.7 \pm 3.2$ & $31.4 \pm 7.1$ & $15.7 \pm 4.7$ & $6.2 \pm 2.9$ & $3.9 \pm 1.0$ & $3.2 \pm 1.2$ & 2.07 \\
\hline -“- & Wisteria sinensis (Sims) DC. & $90.0 \pm 3.4$ & $80.3 \pm 9.4$ & $40.2 \pm 4.1$ & $13.3 \pm 1.8$ & $6.8 \pm 1.1$ & $7.1 \pm 2.8$ & 0.31 \\
\hline Fagaceae & Quercus castaneifolia C. A. Mey. & $50.6 \pm 5.1$ & $23.0 \pm 4.1$ & $14.0 \pm 2.2$ & $13.4 \pm 2.4$ & $7.4 \pm 1.3$ & $7.1 \pm 2.8$ & 2.96 \\
\hline -“- & $\begin{array}{l}\text { Quercus petraea subsp. iberica } \\
\text { (Steven ex M.Bieb.) Krassiln. }\end{array}$ & $94.7 \pm 1.3$ & $48.0 \pm 2.7$ & $17.6 \pm 1.4$ & $10.4 \pm 1.0$ & $8.2 \pm 2.1$ & $7.1 \pm 2.8$ & 0.84 \\
\hline Geraniaceae & Geranium sanguineum L. & $16.3 \pm 1.9$ & $12.0 \pm 1.8$ & $9.9 \pm 1.6$ & $9.7 \pm 1.3$ & $9.5 \pm 1.8$ & $11.9 \pm 1.6$ & - \\
\hline Ginkgoaceae & Ginkgo biloba $\mathrm{L}$. & $92.3 \pm 2.9$ & $49.5 \pm 3.3$ & $17.2 \pm 2.1$ & $10.1 \pm 1.6$ & $7.9 \pm 1.3$ & $7.1 \pm 2.8$ & 0.79 \\
\hline Lamiaceae & Callicarpa bodinieri H. Lev. & $56.1 \pm 1.9$ & $15.1 \pm 3.6$ & $8.2 \pm 5.5$ & $4.6 \pm 2.0$ & $4.7 \pm 2.1$ & $3.7 \pm 2.1$ & 2.67 \\
\hline -“- & Nepeta mussinii Spreng. & $50.7 \pm 4.0$ & $19.4 \pm 4.6$ & $6.3 \pm 1.9$ & $3.6 \pm 1.7$ & $3.8 \pm 1.9$ & $3.7 \pm 2.1$ & 2.95 \\
\hline -“- & Salvia officinalis L. & $26.1 \pm 1.8$ & $12.9 \pm 1.4$ & $5.8 \pm 0.9$ & $2.7 \pm 1.3$ & $2.6 \pm 1.1$ & $3.7 \pm 2.1$ & - \\
\hline -“- & Vitex agnus-castus $\mathrm{L}$. & $30.2 \pm 1.9$ & $19.1 \pm 1.7$ & $10.0 \pm 1.2$ & $10.2 \pm 1.3$ & $9.3 \pm 1.5$ & $11.9 \pm 1.6$ & - \\
\hline -“- & Vitex negundo L. & $62.0 \pm 3.0$ & $44.3 \pm 1.4$ & $11.9 \pm 1.6$ & $9.1 \pm 4.2$ & $6.7 \pm 3.0$ & $3.2 \pm 1.2$ & 1.50 \\
\hline Magnoliaceae & Liriodendron tulipifera $\mathrm{L}$. & $36.4 \pm 3.6$ & $22.4 \pm 1.1$ & $10.8 \pm 0.6$ & $10.4 \pm 2.3$ & $9.5 \pm 1.3$ & $10.9 \pm 1.2$ & - \\
\hline$-“-$ & Magnolia kobus DC. & $97.6 \pm 2.2$ & $72.9 \pm 4.3$ & $44.5 \pm 1.9$ & $14.1 \pm 3.2$ & $7.6 \pm 1.3$ & $7.1 \pm 2.8$ & 0.26 \\
\hline Moraceae & Maclura pomifera (Raf.) Schneid. & $52.6 \pm 14.0$ & $23.6 \pm 4.0$ & $6.2 \pm 1.3$ & $4.4 \pm 2.2$ & $3.8 \pm 1.1$ & $3.2 \pm 1.2$ & 2.80 \\
\hline Phyllanthaceae & Leptopus chinensis (Bunge) Pojark. & $44.7 \pm 1.2$ & $24.2 \pm 2.6$ & $8.4 \pm 0.6$ & $6.2 \pm 2.3$ & $4.1 \pm 1.2$ & $3.2 \pm 1.2$ & - \\
\hline Pinaceae & $\begin{array}{l}\text { Pseudotsuga menziesii (Mirb.) Fran- } \\
\text { co }\end{array}$ & $60.0 \pm 1.7$ & $35.9 \pm 6.7$ & $12.4 \pm 4.1$ & $6.7 \pm 3.4$ & $4.3 \pm 1.9$ & $3.2 \pm 1.2$ & 2.06 \\
\hline Ranunculaceae & Clematis flammula $\mathrm{L}$. & $47.8 \pm 4.2$ & $22.9 \pm 1.5$ & $16.0 \pm 2.5$ & $13.5 \pm 3.4$ & $7.2 \pm 1.5$ & $7.1 \pm 2.8$ & - \\
\hline Rosaceae & Prunus dulcis (Mill.) D. A. Webb & $41.6 \pm 2.4$ & $11.7 \pm 2.7$ & $8.2 \pm 2.1$ & $5.6 \pm 1.9$ & $5.5 \pm 1.4$ & $3.7 \pm 2.1$ & - \\
\hline -“- & Prunus laurocerasus L. & $70.8 \pm 1.7$ & $28.1 \pm 2.0$ & $15.7 \pm 2.4$ & $10.9 \pm 1.9$ & $10.2 \pm 1.0$ & $11.9 \pm 1.6$ & 1.91 \\
\hline Rutaceae & Dictamnus albus L. & $34.9 \pm 4.6$ & $23.1 \pm 3.3$ & $11.8 \pm 2.9$ & $3.0 \pm 1.8$ & $2.7 \pm 1.1$ & $3.7 \pm 2.1$ & - \\
\hline$-“-$ & Phellodendron amurense Rupr. & $64.5 \pm 6.0$ & $48.7 \pm 2.8$ & $20.8 \pm 2.6$ & $5.8 \pm 2.3$ & $4.1 \pm 0.9$ & $3.2 \pm 1.2$ & 0.90 \\
\hline -“- & Ptelea trifoliata $\mathrm{L}$. & $59.0 \pm 8.6$ & $20.5 \pm 1.7$ & $11.1 \pm 2.4$ & $10.6 \pm 1.8$ & $10.4 \pm 1.4$ & $11.9 \pm 1.6$ & 2.47 \\
\hline Simaroubaceae & Ailanthus altissima (Mill.) Swingle & $90.0 \pm 3.3$ & $50.7 \pm 4.0$ & $18.6 \pm 2.5$ & $14.0 \pm 2.3$ & $7.4 \pm 1.2$ & $7.1 \pm 2.8$ & 0.75 \\
\hline Tamaricaceae & Tamarix elongata Ledeb. & $36.0 \pm 5.4$ & $18.4 \pm 2.7$ & $5.6 \pm 1.8$ & $3.9 \pm 2.0$ & $4.1 \pm 1.8$ & $3.7 \pm 2.1$ & - \\
\hline Taxaceae & $\begin{array}{l}\text { Cephalotaxus harringtonia } \\
\text { (Knight ex J. Forbes) K. Koch }\end{array}$ & $63.6 \pm 5.1$ & $45.1 \pm 2.6$ & $10.3 \pm 1.7$ & $7.2 \pm 1.3$ & $6.6 \pm 0.8$ & $3.2 \pm 1.2$ & 1.32 \\
\hline Vitaceae & $\begin{array}{l}\text { Parthenocissus tricuspidata } \\
\text { (Siebold \& Zucc.) Planch. }\end{array}$ & $47.6 \pm 4.5$ & $25.9 \pm 4.8$ & $13.3 \pm 2.5$ & $11.2 \pm 2.4$ & $7.4 \pm 1.4$ & $7.1 \pm 2.8$ & - \\
\hline
\end{tabular}


Table 2

Mortality (\%) of larvae of $S$. papillosus $\mathrm{L}_{3}$ during

$24 \mathrm{~h}$ laboratory experiment $(\mathrm{x} \pm \mathrm{SD}, \mathrm{n}=7)$

exposed to aqueous tinctures of leaves of the plants

\begin{tabular}{llc}
\hline \multicolumn{1}{c}{ Family } & \multicolumn{1}{c}{ Species } & $\begin{array}{c}\text { Mortality of nematode } \\
\text { larvae in } 3.0 \% \text { plant } \\
\text { solution, \% }\end{array}$ \\
\hline Anacardiaceae & Toxicodendron orientale Greene & $0.6 \pm 1.3$ \\
Berberidaceae & Berberis vulgaris L. & $1.3 \pm 2.9$ \\
Celastraceae & Aristolochia manshuriensis Kom. & $9.0 \pm 7.0$ \\
Celastraceae & Celastrus scandens L. & $10.1 \pm 8.1$ \\
Colchicaceae & Colchicum autumnale L. & $10.1 \pm 7.6$ \\
Cupressaceae & Juniperus sabina L. & $6.6 \pm 7.0$ \\
Fabaceae & Laburnum anagyroides Medik. & $9.3 \pm 7.0$ \\
Fabaceae & Securigera varia (L.) Lassen & $6.1 \pm 6.7$ \\
Fabaceae & Wisteria sinensis (Sims) DC. & $9.5 \pm 7.5$ \\
Fagaceae & Quercus petraea subsp. iberica & $10.4 \pm 5.8$ \\
Ginkgoaceae & (Steven ex M.Bieb.) Krassiln. & $7.2 \pm 7.9$ \\
Lamiaceae & Ginkgo biloba L. & $1.7 \pm 3.7$ \\
Lamiaceae & Securigera varia (L.) Lassen & $0.8 \pm 1.7$ \\
Magnoliaceae & Magnolia kobus DC. & $11.0 \pm 9.1$ \\
Simaroubaceae & Ailanthus altissima (Mill.) Swingle & $3.9 \pm 4.0$ \\
Vitaceae & Parthenocissus tricuspidata & $1.2 \pm 2.7$ \\
& (Siebold \& Zucc.) Planch. & \\
\hline
\end{tabular}

Note: for the rest of the concentrations $(0.750 \%, 0.188 \%, 0.047 \%, 0.012 \%)$ of aqueous tinctures of these species of plants the mortality of invasive larvae of S. papillosus $\mathrm{L}_{3}$ was not observed; for all the species indicated in Table 1, but absent in Table 2, mortality of invasive larvae of S. papillosus $\mathrm{L}_{3}$ exposed to the aqueous tinctures of the concentration of $3.00 \%$ and less was also not seen.

Aristolochia manshuriensis Kom. is a Chinese medicinal plant which in certain concentrations is toxic (Zhu, 2002; Hu et al., 2004; Wu et al., 2016).

In nature, Celastrus scandens L. is consumed by birds, though its fruits are also poisonous (Plant Finder. Missouri Botanical Garden). Our studies also indicate high mortality of S. papillosus larvae of the first and second stages of the development exposed for $24 \mathrm{~h}$ to $3 \%$ solutions of C. scandens.

Leaves of Ginkgo biloba L. have a unique chemical composition. Extract of leaves of this medical plant includes over 40 biologically active ingredients. It contains three main groups of substances. The first group is comprised of terpene trilactones, the second of bioflavonoids; the third group is represented by proanthocyanidins or condensed tannins, organic acids (benzoic acid and its derivatives), and also polyphenols, ginkgolic acids, nitrogene bases (thymine), amino acids (asparagines), wax, catechins, steroids, cardanols and other substances (Committee on Herbal Medicinal Products). Long-chain phenols of G. biloba have antimicrobial properties. Bilobol and cardanol are active against Staphylococcus aureus. Anacardic acid inhibits growth of Streptococcus pyogenes, Staphylosoccus aureus, Neisseria gonorrhoeae, Bacillus anthracis, and also has anthelminth properties. Leaves also contain superoxide dismutase enzyme which has antioxidant properties (Zuzuk et al., 2001). Flavoglycosides of G. biloba have high antioxidant activity, and terpenes have an anti-inflammatory effect and improve energy methabolism of the brain. Preparations of this plant contribute to improvement of capillary blood circulation, and also can inhibit the development of metastases from malignant tumours and prevent formation of thrombi (Mohanta et al., 2014). Maltas et al. (2011), in their experiments, studied antioxidant property and total content of phenols in the extracts of G. biloba. Methanol extract exerted high antioxidant activity associated with high content of phenol. The authors also analyzed the content of fatty acids of methanol and acetone extracts from G. biloba. They presume that G. biloba grown in Turkey can be an important source of natural antioxidant.

Traditional Korean medicine broadly uses flower buds of Magnolia kobus DC. for treating various diseases (Cho et al., 2015). Epicuticular leaf waxes of G. biloba and M. grandiflora contain homologic series of carbohydrates, complex waxy ethers, complex ethers benzyl acyls, aldehydes, primary alcohols and fatty acids (Gülz et al., 1992). As a result of our studies, on average $98 \%$. the first and second stage larvae of nematodes exposed for $24 \mathrm{~h}$ died. Thus, the results of the studies mentioned above and also our experiments indicate the necessity of further surveys in this area.

\section{Conclusion}

Invasive larvae of $S$. papillosus and H. contortus in in vitro experiments were resistant to $3 \%$ aqueous tincture of the studied plants. Only the larvae of the third (invasive) stage of S. papillosus died at $24 \mathrm{~h}$ exposure to $M$. kobus, $Q$. petraea, C. autumnale and C. scandens on average $(10-11 \%)$. In in vitro experiments, the most resistant to the influence of the studied plants were the third stage larvae of $H$. contortus. Over $95 \%$ of larvae of this nematode species remained vital after exposure to aqueous tinctures of the plants. Larvae of $S$. papillosus in first and second non-invasive stages were most sensitive to the effects of tinctures of $W$. sinensis, A. altissima, $L$. anagyroides, $Q$. petraea subsp. iberica, G. biloba, C. autumnale, A. manshuriensis, C. scandens, S. varia, $M$. kobus. Mortality of larvae of these stages over $24 \mathrm{~h}$ accounted for $90 \%$. The lowest $\mathrm{LD}_{50}$ were seen during the impacts of $L$. anagyroides, $J$. sabina, C. scandens, $M$. kobus, A. manshuriensis, $W$. sinensis, S. varia, indicating their notable nematocidial property towards $S$. papillosus larvae of the first and second stages.

\section{References}

Abdel-Ghaffar, F., Semmler, M., Al-Rasheid, K. A. S., Strassen, B., Fischer, K., Aksu, G., Klimpel, S., \& Mehlhorn, H. (2010). The effects of different plant extracts on intestinal cestodes and on trematodes. Parasitology Research, 108(4), 979-984.

Albouchi, F., Hassen, I., Casabianca, H., \& Hosni, K. (2013). Phytochemicals, antioxidant, antimicrobial and phytotoxic activities of Ailanthus altissima (Mill.) Swingle leaves. South African Journal of Botany, 87, 164-174.

Al-Snafi, A. E. (2015). The pharmacological importance of Ailanthus altissima a review. International Journal of Pharmacy Review and Research, 5(2), 121-129.

Ayeb-Zakhama, A., Ben Salem, S., Sakka-Rouis, L., Flamini, G., Ben Jannet, H., \& Harzallah-Skhiri, F. (2014). Chemical composition and phytotoxic effects of essential oils obtained from Ailanthus altissima (Mill.) Swingle cultivated in Tunisia. Chemistry and Biodiversity, 11(8), 1216-1227.

Boyko, O. (2008a). Zalezhnist' glybyny migratsiji lychynok nematod pidryadiv Strongylata i Rhabditata vid mekhanichnogo skladu gruntu [Dependence of migration depth of nematodes of Strongylata and Rhabditata nematodes on mechanical soil composition]. Scientific and Technical Bulletin of the Institute of Animal Biology and the State Research Control of the Institute of Veterinary Drugs and Feed Additives, 9(4), 117-121.

Boyko, O. O., \& Brygadyrenko, V. V. (2018). The impact of certain flavourings and preservatives on the survivability of larvae of nematodes of Ruminantia. Regulatory Mechanisms in Biosystems, 9(1), 118-123.

Boyko, O. O., \& Brygadyrenko, V. V. (2019a). The viability of Haemonchus contortus (Nematoda, Strongylida) and Strongyloides papillosus (Nematoda, Rhabditida) larvae exposed to various flavourings and source materials used in food production. Vestnik Zoologii, 53(6), 433-442.

Boyko, O. O., \& Brygadyrenko, V. V. (2019b). Nematocidial activity of aqueous solutions of plants of the families Cupressaceae, Rosaceae, Asteraceae, Fabaceae, Cannabaceae and Apiaceae. Biosystems Diversity, 27(3), 227-232.

Boyko, O. O. (2008). Development of larvae of suborders Strongylata and Rhabditata in differently mineralized soils. Visnyk of Dnipropetrovsk University, Biology, Ecology, 16(2), 8-11.

Bray, D. H., Boardman, P., O’Neill, M. J., Chan, K. L., Phillipson, J. D., Warhurst, D. C., \& Suffness, M. (1987). Plants as a source of antimalarial drugs 5. Activities of Ailanthus altissima stem constituents and of some related quassinoids. Phytotherapy Research, 1(1), 22-24.

Caboni, P., Ntalli, N. G., Aissani, N., Cavoski, I., \& Angioni, A. (2012). Nematicidal activity of (E,E)-2,4-decadienal and (E)-2-decenal from Ailanthus altissima against Meloidogyne javanica. Journal of Agricultural and Food Chemistry, 60(4), 1146-1151.

Cho, H., Sowndhararajan, K., Jung, J.-W., Jhoo, J.-W., \& Kim, S. (2015). Fragrant chemicals in the supercritical carbon dioxide extract of Magnolia kobus DC. flower buds increase the concentration state of brain function. Journal of Essential Oil Bearing Plants, 18(5), 1059-1069.

Deori, K., \& Yadav, A. K. (2015). Anthelmintic effects of Oroxylum indicum stem bark extract on juvenile and adult stages of Hymenolepis diminuta (Cestoda), an in vitro and in vivo study. Parasitology Research, 115(3), 1275-1285. 
El-Rigal, N. S, Aly, S. A., Rizk, M., \& Said, A. (2006). Use of Ailanthus altissima and Ziziphus spina christi extracts as folk medicine for treatment of some hepatic disorders in Schistosoma mansoni infected mice. Trends in Medical Research, 1(2), 100-112.

Forrester, R. (1979). “Have you eaten laburnum?” The Lancet, 313(8125), 1073.

Gogoi, S., \& Yadav, A. (2016). In vitro and in vivo anthelmintic effects of Caesalpinia bonducella (L.) Roxb. leaf extract on Hymenolepis diminuta (Cestoda) and Syphacia obvelata (Nematoda). Journal of Intercultural Ethnopharmacology, 5(4), 427

Gu, X., Fang, C., Yang, G., Xie, Y., Nong, X., Zhu, J., Wang, S., Peng, X., \& Yan, Q. (2013). Acaricidal properties of an Ailanthus altissima bark extract against Psoroptes cuniculi and Sarcoptes scabiei var. cuniculi in vitro. Experimental and Applied Acarology, 62(2), 225-232.

Gülz, P.-G., Müller, E., Schmitz, K., Marner, F.-J., \& Güth, S. (1992). Chemical composition and surface structures of epicuticular leaf waxes of Ginkgo biloba, Magnolia grandiflora and Liriodendron tulipifera. Zeitschrift Für Naturforschung C, 47, 516-526.

Hu, S.-L., Zhang, H.-Q., Chan, K., \& Mei, Q.-X. (2004). Studies on the toxicity of Aristolochia manshuriensis (Guanmuton). Toxicology, 198, 195-201.

Jiang, J. M., Yang, L., Fei, S. M., Mo, K. L., \& Sun, Q. X. (2013). Mollusicidal effects of some species of plants in hilly and mountainous areas. Zhongguo Xue Xi Chong Bing Fang Zhi Za Zhi, 25(3), 255-258.

Jiang, Y. H., Fan, X. H., \& Jiang, H. (2009). Extraction of Wisteria sinensis active constituent and its inhibitory effect on fungi and bacteria. Journal of Henan Agricultural Sciences, 38(3), 60-62. (in Chinese).

Keskin, S., Sirin, Y., Cakir, H. E., \& Keskin, M. (2019). Phenolic composition and antioxidant properties of Wisteria sinensis. International Journal of Scientific and Technological Research, 5(2), 98-103.

Lü, J. H., \& Shi, Y. L. (2011). The bioactivitiy of essential oil from Ailanthus altissima Swingle (Sapindales: Simaroubaceae) bark on Lasioderma serricorne (Fabricius) (Coleoptera: Anobiidae). Advanced Materials Research, $365,428-432$.

Maltas, E., Vural, H. C., \& Yildiz, S. (2011). Antioxidant activity and fatty acid composition of Ginkgo biloba from Turkey. Journal of Food Biochemistry, 35(3), 803-818.

Mohamed, M. A., Hamed, M. M., Abdou, A. M., Ahmed, W. S., \& Saad, A. M. (2011). Antioxidant and cytotoxic constituents from Wisteria sinensis. Molecules, 16(5), 4020-4030.

Mohanta, T. K., Tamboli, Y., \& Zubaidha, P. K. (2014). Phytochemical and medicinal importance of Ginkgo biloba L. Natural Product Research, 28(10), 746-752.
Okunade, A. L., Bikoff, R. E., Casper, S. J., Oksman, A., Goldberg, D. E., \& Lewis, W. H. (2003). Antiplasmodial activity of extracts and quassinoids isolated from seedlings of Ailanthus altissima (Simaroubaceae). Phytotherapy Research, 17(6), 675-677.

Poljuha, D., Sladonja, B., Šola, I., Dudaš, S., Bilić, J., Rusak, G., Motlhatlego, K. E., \& Eloff, J. N. (2017). Phenolic composition of leaf extracts of Ailanthus altissima (Simaroubaceae) with antibacterial and antifungal activity equivalent to standard antibiotics. Natural Product Communications, 12(10), 1201.

Reshetniak, D. Y., Pakhomov, O. Y., \& Brygadyrenko, V. V. (2017). Possibility of identifying plant components of the diet of Harpalus rufipes (Coleoptera, Carabidae) by visual evaluation. Regulatory Mechanisms in Biosystems, 8(3), 377-383.

Temjenmongla, Yadav, A., \& Deori, K. (2015). Anthelmintic effects of Psidium guajava and Lasia spinosa on Hymenolepis diminuta (Cestoda): A scanning electron microscopic study. Journal of Advanced Microscopy Research, 10(1), 20-23.

Wu, L., Wang, B., Zhao, M., Liu, W., Zhang, P., Shi, Y., Xiong, C., Wang, P., Sun, W., \& Chen, S. (2016). Rapid identification of officinal Akebiae caulis and its toxic adulterant Aristolochiae manshuriensis caulis (Aristolochia manshuriensis) by loop-mediated isothermal amplification. Frontiers in Plant Science, 2016, 7 .

Yadav, A. K., \& Tangpu, V. (2011). Anthelmintic activity of ripe fruit extract of Solanum myriacanthum Dunal (Solanaceae) against experimentally induced Hymenolepis diminuta (Cestoda) infections in rats. Parasitology Research, 110(2), 1047-1053.

Yevstafieva, V. A., Kravchenko, S. O., Gutyj, B. V., Melnychuk, V. V., Kovalenko, P. N., \& Volovyk, L. B. (2019). Morphobiological analysis of Trichuris vulpis (Nematoda, Trichuridae), obtained from domestic dogs. Regulatory Mechanisms in Biosystems, 10(2), 165-171. http://doi.org/10.15421/021924

Zajac, A. M., \& Conboy, G. A. (Eds.). (2011). Veterinary clinical parasitology. 8th ed. John Wiley and Sons, London.

Zazharska, N., Boyko, O., \& Brygadyrenko, V. (2016). Influence of diet on the productivity and characteristics of goat milk. Indian Journal of Animal Research, 52(5), 711-717.

Zhu, Y.-P. (2002). Toxicity of the chinese herb Mu Tong (Aristolochia manshuriensis). Adverse Drug Reactions and Toxicological Reviews, 21(4), 171-177.

Zuzuk, B. M., Kutsik, R. V., Darmogray, R. E., \& Tomchuk, Y. (2001). Ginkgo biloba (analiticheskij obzor) [Ginkgo biloba (analytical review)]. Pharmacist (Kharkov), 19, 34-38 (in Ukrainian). 